\title{
Pertentangan Hukum Adat Dengan Hukum Islam Dalam Kasus Waris Janda Poligami 'Urang' Banjar
}

\author{
Rahmat Fadillah \\ Fakultas Syariah \\ Universitas Islam Negeri Antasari \\ Jalan Ahmad Yani Km. 4.5 Banjarmasin, Kalimantan Selatan
}

\begin{tabular}{l} 
Article Info \\
\hline Article history: \\
Received Aug 12th 2020 \\
Revised Aug 29th 2020 \\
Accepted Feb 15th, 2021 \\
\hline
\end{tabular}

Keyword:

Hukum, Hukum Adat, Hukum Islam, poligami, janda, waris.

\begin{abstract}
Marriage is something sacred and has a binding and lasting impact on husband and wife, sometimes there is a husband's desire to have polygamy. In various countries where people adhere to Islam, it is justified to practice polygamy by Islamic law. However, from a polygamous relationship can cause problems, many of which are about inheritance. If a polygamous husband dies, then the distribution of the husband's inheritance becomes a confrontation for the wives who are left behind if the procedure for the distribution is unclear, whether to use Islamic law or use customary law. An example of this confrontation can be found in the Banjar community of South Kalimantan. By examining cases in the banjar community, it is hoped that we can find out what the phenomenon looks like, what laws are used by them and what is the perspective of Islamic law on the confrontation of this polygamous widow's inheritance. By using a normative literature method and a few interviews and observations in the field, this research finally gets the results that if a custom in Indonesia is against the law and ethics in sharia, it is no longer necessary to defend it. Because the position of god's law (sharia) is a very high and eternal law. This is following the reception a contrario theory. The importance of socialization and understanding to the public about legal knowledge in the field of inheritance, be it customary inheritance, positive legal inheritance, and Islamic inheritance, needs to be considered by various parties with various perspectives. And a good marriage is a marriage that from the beginning was intended to strengthen a lasting bond (mitshaqon ghalizon) so that the efforts in the process of achieving it are carried out as well as possible, according to the guidance of Islam which is rahmatan lil 'alamin.
\end{abstract}




\begin{abstract}
Abstrak: Pernikahan merupakan sesuatu yang sakral dan memberikan dampak yang mengikat serta abadi bagi pasangan suami isteri, terkadang ada keinginan suami untuk berpoligami. Diberbagai negara yang masyarakatnya menganut agama Islam dibenarkan untuk melakukan poligami oleh Hukum Islam. Akan tetapi dari sebuah hubungan poligami dapat menimbulkan permasalahan yang banyak diantaranya yaitu tentang harta warisan. Jika suami yang berpoligami meninggal maka tidak sedikit pembagian harta warisan suami tersebut menjadi pertentangan penetapan hukum yang digunakan bagi isteriisterinya yang ditinggalkan jika tata cara pembagiannya tidak jelas, apakah menggunakan Hukum Islam atau menggunakan Hukum Adat. Contoh Pertentangan ini dapat ditemui pada masyarakat banjar kalimantan selatan. Dengan kita meneliti kasus di masyarakat banjar ini diharapkan dapat mengetahui seperti apa fenomenanya, Hukum apa yang digunakan oleh mereka dan bagaimana persfektif Hukum Islam terhadap pertentangan warisan janda poligami ini. Dengan menggunakan metode kepustakaan yang bersifat normatif dan sedikit wawancara serta observasi di lapangan maka akhirnya penelitian ini mendapatkan hasil bahwa apabila suatu adat istiadat di Indonesia ini bertentangan dengan hukum dan etika dalam syariah maka tidak perlu lagi untuk dipertahankan. Karena posisi hukum tuhan (syariah) adalah hukum yang sangat tinggi dan eternal. Hal ini sesuai dengan teori reception a contrario. Pentingnya sosialisasi dan pemahaman kepada masyarakat tentang ilmu pengetahuan hukum dalam bidang waris baik itu waris adat, waris hukum positif, dan waris Islam, perlu diperhatikan oleh berbagai pihak dengan berbagai sudut pandang. Dan pernikahan yang bagus adalah pernikahan yang sejak awal di niatkan dalam meneguhkan ikatan yang abadi (mitshaqon ghalizon) sehingga upaya dalam proses pencapaiannya itu di laksanakan sebaik-baik mungkin, sesuai tuntunan agama Islam yang rahmatan lil 'alamin.
\end{abstract}

Corresponding Author: Email: rahmatfadillah70@gmail.com

(C) 2021 The Authors. Published by Fakultas Syariah UIN Antasari.

This is an open access article under the CC BY license

(https://creativecommons.org/licenses/by/4.0)

\title{
Pendahuluan
}

Dalam kehidupan nyata saat ini masih ada kita temui pernikahan yang bersifat poligami bahkan viral. Sedangkan yang dimaksud dengan poligami adalah seorang laki-laki beristeri lebih dari satu orang, tetapi dibatasi pula paling banyak adalah empat orang.

Mengapa poligami ini dibatasi hanya empat orang saja? Karena apabila lebih empat orang berarti tidak sesuai dengan syariat agama Islam, demi kemaslahatan hidup berumah tangga. Allah Swt berfirman dalam surah An-Nisa ayat 3: 


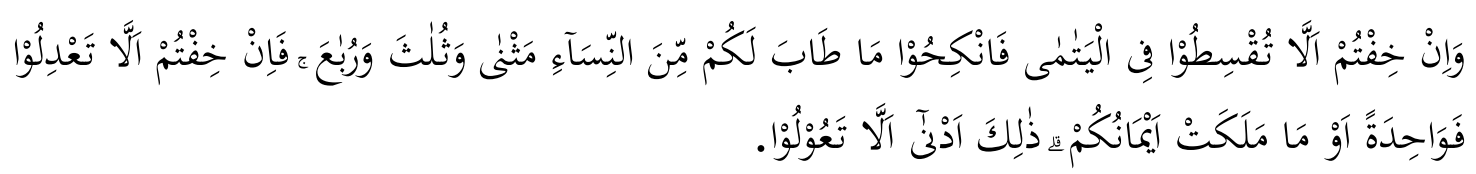

Artinya: Dan jika kamu khawatir tidak akan mampu berlaku adil terhadap (hak-hak) perempuan yatim (bilamana kamu menikahinya), maka nikahilah perempuan (lain) yang kamu senangi: dua, tiga atau empat. Tetapi jika kamu khawatir tidak akan mampu berlaku adil, maka (nikahilah) seorang saja, atau hamba sahaya perempuan yang kamu miliki. Yang demikian itu lebih dekat agar kamu tidak berbuat zalim. (Q.S An-Nisa : 3) ${ }^{1}$

Dari ayat tersebut dapat diambil kesimpulan yang sangat jelas bahwa dalam sebuah keluarga poligami tentulah suami harus dapat berlaku adil demi menegakkan kesejahteraan, ketenteraman, dan kedamaian yang diharapkan dalam keluarganya itu.

Untuk mencapai tujuan adil tersebut sangat sulit bagi suami dalam menjalankannya tanpa adanya ikatan dan rasa kekeluargaan dan sikap saling menghormati dari seluruh komponen keluarga itu sendiri. Ada kalanya rasa kekeluargaan dan sikap saling menghormati tersebut diuji dengan berbagai macam permasalahan yang datang baik dari luar maupun dari dalam keluarga itu sendiri, baik pada waktu pernikahan maupun pasca pernikahan. Salah satu contoh permasalahan keluarga poligami yang hadir pasca pernikahan adalah apabila ada seorang suami yang berpoligami meninggal dan memiliki harta warisan, yang mana warisan tersebut akan mendatangkan pertentangan (sengketa) dalam pembagiannya. Para isteri yang ditinggalkan oleh almarhum suaminya inilah yang nantinya akan saling bersengketa atas harta warisan suami mereka.

Terkait mengenai warisan pada dasarnya hukum mempelajari ilmu kewarisan itu adalah kifayah, maka tidak semua orang diwajibkan menguasai ilmu faraid ini, demikian pula halnya dengan janda poligami, sebagian dari mereka belum mengetahui betapa pentingnya mempelajari ilmu kewarisan (ilmu faraid). Karena memang tidak pernah mempelajari dan ada pula yang memang tidak mengetahui dan tidak peduli tentang tata cara pembagian warisan menurut hukum Islam, sehingga mereka mengalami keterbatasan pengetahuan dalam ilmu faraid. Padahal sesungguhnya ilmu faraid ini adalah merupakan ilmu yang penting dan sangat perlu untuk dipelajari, karena apabila tidak ada lagi seorang pun yang mempelajarinya maka ilmu faraid ini ada kemungkinan akan musnah.

Sebagaimana hadits yang diriwayatkan oleh Imam Ahmad, At Tirmidzi dan AlNassa'i, bahwa Rasulullah bersabda:

$$
\begin{aligned}
& \text { تعلموا القران وعلموه النا س وتعلموالفرا ئض وعلموها النا س فاءنى امرؤ مقبوض والعلم مر فو ع ويوشك ان يختلف } \\
& \text { اثنان في الفريضة فلا يجدا يخبرهما2. }
\end{aligned}
$$

Artinya: “Belajarlah Al-Qur'an dan ajarkanlah dia kepada manusia dan belajarlah faraid karena sesungguhnya kau seorang yang akam mati, dan ilmu akan terangkat, dan bisa

\footnotetext{
${ }^{1}$ Al-Qur'an Tajwid Warna, Terjemah Indonesia: Plus Transliterasi Latin (Shahih, 2015), 77.

2 Rafiq Ahmad, Fiqh Mawaris (Jakarta : PT Raja Grafindo, 2001), h. 6
} 
jadi akan ada dua orang yang berselisih, tetapi tak akan bertemu mereka seorang yang akan mengabarkan kepada mereka (hukumya)". ${ }^{3}$

Individu masyarakat banjar yang biasa disebut dengan 'urang banjar' / orang banjar khususnya dalam hal ini yaitu janda poligami yang memiliki latar belakang pendidikan Sekolah Menengah Atas kebawah, mereka akan menemukan permasalahan yang menjadi sebuah pertentangan dalam hal pembagian harta warisan sepeninggal suamiya. Pertentangan yang biasanya mereka temukan diantaranya yaitu adanya penguasaan penuh terhadap harta warisan dari salah satu janda poligami karena merasa paling berhak dengan berbagai alasan atas warisan yang ditinggalkan oleh almarhum suaminya. Adanya perasaan atau sikap tidak rela dan tidak ikhlas dari janda poligami yang mengakibatkan tidak terjalinnya silaturrahmi yang baik karena tidak menerima bagian warisan secara adil atau sesuai dengan hukum Islam.

Dalam upaya penyelesaian pertentangan terhadap permasalahan yang dihadapi ini sebagian janda poligami yang tidak mengetahui ilmu faraid, mereka memiliki cara penyelesaian tersendiri, diantaranya yaitu dengan alasan 'urf/kebiasaan yang dianggap sebagai hukum adat (budaya): 1 . factor kedekatan dengan suami mereka di saat masih hidup, dan 2. factor senioritas. Sehingga janda poligami ini membagikan warisan tanpa mengutamakan hukum faraid Islam yang mana semestinya para janda poligami tersebut masing-masing mendapat seperempat bagian bila pewaris tidak meninggalkan anak, dan bila pewaris meninggalkan anak maka janda mendapat seperdelapan bagian saja. ${ }^{4}$

Disamping itu juga masih ada janda poligami yang mengerti dan mengajukan pertentangan ini ke Pengadilan Agama. Mereka meyakini bahwa apabila diselesaikan di Pengadilan Agama berarti sudah menjalankan perintah Allah SWT dan menegakkan hukum di negeri Republik Indonesia ini. Hal ini sudah sesuai dengan hadits Rasul:

$$
\text { عن ابن عباس قال : قا ل رسو ل الله صلى الله عليه وسلم : اقسموا الما ل بين اهل الفرئض على كتا ب الله }
$$

Artinya: Dari Ibnu Abbas, ia berkata: “Rasulullah SAW. Bersabda: 'Bagikanlah harta warisan itu kepada para ahli waris yang mendapat bagian pasti sesuai dengan kitab Allah. Adapun sisanya, maka bagi laki laki yang paling dekat nasabnya'," ${ }^{6}$

Terkait penyelesaian pertentangan pembagian waris janda poligami yang dilakukan tidak pada Pengadilan Agama ini, memiliki keunikan tersendiri, dimana para janda poligami tersebut mengedepankan sistem pembagian warisan dengan asas kedekatan dengan suami mereka dan asas senioritas yang dianggap sudah membudaya sejak zaman dahulu, dan merupakan adatnya 'urang banjar' seperti demikain.

Dari beberapa fenomena yang penulis temukan dilapangan ini maka ada beberapa hal yang menarik dan penting untuk diteliti secara komprehensif terhadap pertentangan hukum waris janda poligami ini. Oleh karena itu penulis berusaha

${ }^{3}$ A. Hasan, Al-Fara'idh, kitab pembagian puska cara Islam dengan alasan-alasan Qur'an, dan Hadits, cetakan ke XII, (jakarta : 1972), h.1

${ }^{4}$ Direktorat pembinaan badan peradilan agama Islam direktorat jenderal pembinaan kelembagaan agama Islam, Kompilasi Hukum Islam di Indonesia, (Jakarta : Departemen Agama RI 2001), h. 85

${ }^{5}$ Abi Al -Husayni Muslim, Shabih Muslim, Juz 3 (Beirut : Dar Al-kitab Al-Ilmiah. 1998), h. 67.

${ }^{6}$ Abid Bisri Mosthofa, Terjemahan Sabih Muslim, Jilid III ( Semarang: Asy Syifa.1993 ), h.146. 
mengangkat penelitian ini dalam bentuk sebuah karya ilmiah dan nantinya akan dijadikan jurnal hukum adat atau jurnal hukum syariah.

Seperti apa sebenarnya hukum adat terkait waris janda poligami 'urang banjar' ini, dan bagaimana dalam persfektif hukum Islam? Melalui dua pertanyaan ini akan penulis bahas secara sistematis pada poin pembahasan selanjutnya.

\section{A. Metode Penulisan}

Penelitian ini pada dasarnya merupakan penelitian normatif, yakni penelitian yang meneliti tentang norma-norma yang berlaku dalam masyarakat banjar khususnya di Kabupaten banjar, tentang hukum waris adat dari pertentangan hukum kewarisan para janda poligami. Akan tetapi juga penelitian ini diperkuat dengan data empiris tentang norma hukum pelaksanaan pembagian harta warisan janda poligami. Penulis meminta data ke beberapa Pengadilan agama tentang pernah adanya pertentangan itu, kemudian mendatangi satu-persatu dan melakukan interview kepada para pelaku pertentangan hukum kewarisan ini beserta keluarganya yang ada.

Penelitian ini dilakukan secara random, dan melaksanakan interview kepada mereka para janda poligami tersebut, ditambah lagi wawancara juga kepada keluargakeluarga mereka. Tentunya untuk mencari alamat mereka tidak mudah sehingga peneliti memerlukan informan yang memahami wilayah dimana para subyek penelitian berada. Penelitian ini masih terfokus pada wilayah Kabupaten Banjar saja, dan poses penelitiannya memakan waktu hampir satu tahun lamanya. Seluruh data di kolektif dan diberi tanggal kapan dilaksanakannya wawancara hingga akhirnya dianalisis berdasarkan pendekatan Normatif. Agar dapat menjadi gambaran yang komprehensif maka akan penulis jelaskan pada bagian pembahasan permasalahan dalam tulisan karya ilmiah ini.

\section{B. Pembahasan}

Perkara yang dibahas dalam penelitian ini adalah tentang perkara pertentangna hukum kewarisan janda poligami 'urang' banjar. Seperti apa sebenarnya hukum adat terkait waris janda poligami 'urang banjar' ini, dan bagaimana dalam persfektif hukum Islam. Akan penulis ulas pada poin pembahasan ini. Akan tetapi sebelumnya penulis akan menyajikan terlebih dahulu beberapa kasus pertentangan hukum kewarisan yang penulis temui di lapangan.

1. Pertentangan dalam kasus pertama

a. Identitas

$\begin{array}{ll}\text { Nama } & :(\mathrm{Hj} . \mathrm{SK}) \\ \text { Umur } & : \text { 65 Tahun } \\ \text { Pendidikan } & \text { : SD } \\ \text { Pekerjaan } & \text { : Ibu rumah tangga } \\ \text { Agama } & \text { : Islam }\end{array}$


Alamat $\quad$ : Komp. Asdi Karya II RT. 6 / A RW. 2 No.1 Desa Kertak Hanyar II Kec. Kertak Hanyar Kab. Banjar.

b. Uraian

Hj. SK adalah seorang janda poligami yang ditinggal mati suaminya pada tanggal 5 bulan Safar 1403 H / 18 Mai 1983 (kurang lebih 25 Tahun yang lalu). Selama perkawinannya Hj. SK dengan suaminya (H. MSR) tidak mempunyai anak.

H. MSR meninggalkan warisan berupa sebuah rumah seharga Rp. 15.000.000., tabungan uang di bank sebanyak Rp. 75.000.000.-, sebidang tanah yang diatasnya sedang dibangun rumah untuk Hj. SK seharga Rp. 40.000.000.-

Ketika suaminya meninggal Hj. SK tidak mendapat bagian warisan, karena suaminya selama sakit sebelum meninggal dunia tinggal dirumah isteri kedua yaitu (Y) dan semua urusan warisan di tangani oleh $\mathrm{Y}$ dengan alasan dia yang lebih berhak karena memelihara suaminya sebelum meninggal, dan menurutnya hal itu sudah biasa dalam permasalahan waris di masyarakat banjar, dan sering terjadi sejak dulu kala bahkan ini sudah tradisi atau merupakan Hukum adat setempat. Perkawinan Y dengan H. MSR juga tidak dikaruniai anak.

Hj. SK tidak bisa mengambil bagian warisan dari almarhum suaminya karena dia merasa tidak mempunyai daya upaya apapun untuk melakukan tindakan itu, sementara saat ini Hj. SK tinggal sebatang kara dengan mengharapkan penghasilan dari rumah sewaan kecil yang dimilikinya untuk kehidupan sehari hari. Hj. SK sebenarnya tahu akan keberadaan harta warisan yang ditinggalkan almarhum suaminya itu dan beliau merasa tidak ridha selama harta warisan itu tidak dibagikan sebagaimana mestinya.

Berdasarkan keterangan $\mathrm{Hj}$. SK sebidang tanah yang saat ini diatasnya akan dibuatkan rumah untuknya sudah diwariskan kepada adik suaminya dan terjual kepada (H. NI) seharga Rp. 40.000.000.-. dari penjualan tanah tersebut $\mathrm{Hj}$. SK mendapatkan bagian Rp. 10.000.000.-. Hj. SK menjelaskan bahwa dalam perjanjian jual beli tanah tersebut akan dibangunkan diatasnya sebuah rumah, dan rumah itu dihuni oleh beliau sendiri sampai beliau wafat. ${ }^{7}$ Akan tetapi pada kenyataannya tidak demikian. Dan ini sangat bertentangan dengan Hukum Islam.

2. Pertentangan dalam Kasus kedua

a. Identitas

$\begin{array}{ll}\text { Nama } & :(\mathrm{MR}) \\ \text { Umur } & : \text { 45 Tahun } \\ \text { Pendidikan } & : \text { MIN } \\ \text { Pekerjaan } & \text { : Ibu rumah tangga } \\ \text { Agama } & \text { : Islam }\end{array}$

7 Wawancara, Kertak Hanyar, 14.00 WITA. 
Alamat : : Gg. Samiya RT. 6 / B RW. 2 Kel. Kertak Hanyar I Kec. Kertak Hanyar Kab. Banjar

b. Uraian

MR adalah seorang janda poligami sejak 15 tahun yang lalu. Dia adalah isteri kedua dari (H. BS). Setelah suaminya meninggal, MR menikah lagi dan bersuamikan seorang duda yang berprofesi sebagai supir taksi. Mereka hidup dengan kehidupan yang sederhana.

H. BS meninggal dunia dengan meninggalkan beberapa harta warisan diantaranya yaitu: berupa sebidang tanah yang akan dijual seharga Rp. 500.000.000., satu buah rumah (Type $4 \times 6 \mathrm{M} 2$ ), dan dua buah mobil bus dengan harga Rp. 140.000.000.--

Semua harta warisan itu dikuasai sepenuhnya oleh isteri pertama almarhum H. BS yaitu (Hj. IS). Sedangkan Hj. IS tidak mau membagikan harta warisan itu sendiri karena merasa sebagai isteri pertama dan merasa paling berhak atas warisan dari suaminya tersebut menurutnya dalam Hukum adat banjar siapa yang paling tua atau senior maka dialah yang bekuasa dan bisa menentukan warisan tersebut dibagikan atau tidak dibagikan. Padahal Hj. IS juga sudah mengetahui bahwa suaminya tersebut mempunyai isteri kedua yaitu MR.

Selama berpoligami H. BS hanya dikaruniai dua orang putra dari istrinya $\mathrm{Hj}$. IS. Sedangkan MR tidak bisa memberikan buah hati kepadanya. MR sebenarnya belum bisa merelakan atas tindakan $\mathrm{Hj}$. IS yang keras kepala menguasai harta warisan dari alamarhum suami mereka tersebut. Berdasarkan pengakuan MR ada seseorang yang menanyakan kepadanya bahwa mengapa beliau tidak mengambil hak atau bagian dari warisan yang ditinggalkan oleh suaminya tersebut? Akan tetapi MR menjawabnya dengan diam saja, padahal menurutnya mengapa dia tidak mengambil bagian dari warisan suaminya tersebut semata-mata karena dia tidak ada daya upaya atau karena tidak adanya seorang pun yang dapat membantunya dalam menyelesaikan permasalahan ini. terlebih untuk membawanya ke Pengadilan Agama agar diselesaikan secara Hukum Islam. MR hanya bisa pasrah dan menerima dengan apa adanya.

Lima belas tahun sudah berlalu dan MR tetap saja tidak mendapatkan bagian dari harta warisan sepeninggal almarhum suaminya tersebut. Hubungan silaturrahmi diantara MR dan Hj. IS pun semakin renggang. ${ }^{8}$

3. Pertentangan dalam kasus ketiga

a. Identitas

$\begin{array}{ll}\text { Nama } & :(\mathrm{SJ}) \\ \text { Umur } & : 46 \text { Tahun }\end{array}$

8 Wawancara, Kertak Hanyar, 19.30 WITA. 


$\begin{array}{ll}\text { Pendidikan } & \text { :SMP } \\ \text { Pekerjaan } & \text { : Swasta } \\ \text { Agama } & \text { : Islam } \\ \text { Alamat } & \text { : Jl. Martapura Lama Gudang Hirang RT. 024 RW. 011 Desa Gudang } \\ & \text { Hirang, Kec. Sungai Tabuk Kab. Banjar. }\end{array}$

b. Uraian

SJ adalah seorang janda poligami. Sudah sekitar 13 Tahun SJ ditinggal mati suaminya yaitu (H. AB) pada bulan Agustus 1994. Sekarang SJ dengan ketiga anaknya Satu orang laki-laki dan dua orang perempuan hidup dengan sederhana.

$\mathrm{H}$. AB meninggalkan harta peningalan yaitu sebuah rumah di Beruntung, sebidang tanah di Bunyamin 40M2, satu unit mobil jimny Katana, satu unit mobil Jet Star.

Berdasarkan pengakuan SJ pembagian harta warisan ini seutuhnya hanya dikuasai oleh isteri pertama $\mathrm{H}$. AB yaitu $(\mathrm{Hj}$. $\mathrm{RHN})$ dengan alasan dia paling dia adalah isteri yang paling tua dan memang sepatutnyalah dalam kebiasan 'urang banjar' (Hukum adat) isteri pertama yang paling berkuasa terlebih banyak terhadap harta warisan suami.

Memang harta warisan tersebut sebagian besar berada di tempat isteri pertama. Sedangkan harta yang ada pada isteri kedua hanya sebuah rumah yang ada di Berutung tersebut diatas. Harta yang sudah terjual yang diketahui oleh SJ yaitu: Sebidang tanah (40M2) di Komplek perumahan Bunyamin dengan harga Rp. 475.000.000.-, mobil Jimny Katana seharga Rp. 15.000.000.-, mobil Jet Star seharga Rp. 7.000.000.-, semuanya ini terjual oleh isteri pertama beserta anak - anaknya, sedangkan Rumah di Beruntung terjual oleh SJ sendiri dengan harga jual Rp. 52.000.000.- untuk keperluan kehidupannya.

Hasil penjualan rumah tersebut diatas di belikan SJ kesebuah mobil mini Van (taksi kuning) dan di usahakan oleh anak laki - lakinya yaitu Iyus (IY). IY adalah anak dari hasil perkawinannya dengan almarhum suaminya H. AB. Setelah dua tahun IY tidak lagi menjadi supir taksi akan tetapi ia bekerja dengan membantu teman untuk menjalankan mobil truk pengangkut material hingga akhirnya dia bisa membeli sebuah mobil truk sendiri. Dari pengakuan IY, bukannya keberuntungan yang dia dapat dari usaha menjalankan truk miliknya itu, akan tetapi kerugian yang dia peroleh karena dia harus memperbaiki dan membeli berbagai suku cadang untuk mobil truk tersebut.

Bukannya menambah penghasilan sehari hari, malah sebaliknya mobil truk tersebut menambah beban bagi kehidupan mereka sampai akhirnya mobil itu terjual. Hingga sampai sekarang SJ berusaha hidup dengan penghasilannya menjual kue. Melihat keadaan seperti ini IY berusaha membantu ibunya dengan ikut seseorang pengusaha dalam menjalankan mobil truk pengangkut material milik pengusaha tersebut. 
SJ sering sekali mengeluh tentang pembagian harta warisan ini. Dia merasa tidak adil diperlakukan, SJ juga tidak rela dan tidak lega hati kalau harta warisan itu masih saja tidak dibagikan kepadanya, apa lagi kalau SJ teringat akan ketulusannya saat dia merawat suaminya itu selama dua tahun setengah sebelum beliau meninggal dunia.

H. AB sempat dirawat di RS Darmo Surabaya selama satu bulan setengah dan kemudian dikembalikan ke RS Islam Banjarmasin hingga meninggal dunia. Selama itu juga SJ merasa hanya dialah yang benar benar merawat suaminya tersebut.

Akan tetapi disisi lain SJ dan IY mempunyai pendapat tersendiri akan harta warisan tersebut yaitu "bagaimanapun uang dari harta warisan itu diusahakan maka hasilnya tidak akan beruntung" mengapa demikian karena berdasarkan pengakuan SJ semasa $\mathrm{H}$. AB masih dalam masa perawatan pernah beramanat kepada isteriisterinya agar apabila beliau meningal dunia kelak, mereka harus membagikan harta warisan beliau secara adil (dibagi rata / dibagi dua) atau di bagi sesuai faraidh Islam (Hukum Islam) di Pengadilan Agama. Akhirnya SJ hanya bisa pasrah dan diam terhadap perlakuan $\mathrm{Hj}$. RHN tersebut. ${ }^{9}$

Setelah memaparkan tiga kasus pertentangan kewarisan tersebut, penulis memahami bahwa ada satu sikap dan tindakan oleh janda poligami yang menguasai harta warisan tersebut bahwasanya dalam hal menguasai harta warisan almarhum suaminya tersebut dari janda poligami yang lainnya itu adalah suatu hal yang sudah menjadi kebiasaan atau 'urf dalam hukum adat banjar yang membudaya berdasarkan asas kedekatan dengan suami mereka dan asas senioritas.

Secara filosofis budaya, memang budaya banjar tidak bisa terlepas dari budaya primitive yang sudah ada sejak zaman dulu yaitu dimana mereka memahami siapa yang kuat, maka dialah yang berkuasa, walaupun pada faktanya saat ini sudah banyak percampur-bauran dari budaya tersebut dengan budaya religiusitas dan bahkan sedikit dirasa masuk budaya barat yaitu liberalisitas. Jika kita kaitkan dengan filosofis kerajaan yaitu Kerajaan Negara Daha dan Negara Dipa, bisa jadi benar. Karena dalam sistem kewarisan Hindu, asas dalam pewarisan itu adalah: 1. Keutuhan, 2. Keutamaan, 3. Ketergantungan, 4. Kebersamaan, 5. Keberlanjutan. 6. Kemanfaatan. Yang mana pewarisan tidak identic dengan membagi harta peninggalan orang tuannya dan leluhur oleh ahli waris, melainkan mengandung makna pelestaraian, pengurusan dan penerusan hak (swadikara) dan tanggung jawab (swardharma) terhadap peninggalan pewaris dalam berbagai wujud dan sifatnya. ${ }^{10}$

Hal ini sesuai dengan pandangan peneliti hukum adat yaitu V.E. Korn tahun 1932 bahwa ciri khas hukum adat Hindu adalah bertujuan agar sebanyak dan sedapat mungkin harta pusakan tetap utuh dan dipegang serta diurus oleh seorang kepala keluarga (pemimpin penerus kelestarian), maka dengan sendirinya pembagianpembagian jarang dilakukan. Karena itu juga hasrat untuk menetapkan bagian-bagian tertentu tidak sangat dirasai.

\footnotetext{
${ }^{9}$ Wawancara, Sungai tabuk, 16.00 WITA.

${ }^{10}$ Wayan P Windia, "SISTEM PEWARISAN MENURUT HUKUM ADAT BALI,” n.d., 11.
} 
Disamping itu penulis juga menemukan bahwa secara spesifik dalam harta warisan adat terdiri atas harta yang dapat dibagi dan harta yang tidak dapat dibagi, karena dalam hukum waris adat tidak mengenal yang namanya "legitime portie" seperti yang ada pada KUH Perdata (Hukum Positif) pasal 913 dan pasal 1066. Hukum waris adat juga tidak mengenal adanya hak bagi waris untuk sewaktu-waktu menuntut agar harta warisan dibagikan kepada para waris. Disinilah letak keunikan dari kasus pertentangan hukum kewarisan tersebut sehingga perlu diteliti secara mendalam dan konfrehensif jika memungkinkan.

Sebelum masuk pada persfektif hukum islam terhadap pertentangan hukum kewarisan janda poligami 'urang' banjar ini, penulis akan sedikit menyentuh perspektif antropologi adat 'urang' banjar. Penulis dapati bahwa ada filsafat hidup yang dimiliki oleh orang suku banjar, salah duanya adalah: 1. Orang banjar itu kompetitif individual, yaitu terkenal pekerja keras untuk suatu cita-citanya tetapi bekerja sendiri-sendiri tidak secara kolektif, sehingga urang banjar cenderung memiliki sifat individual dan ego yang tinggi sehingga susah diatur. Dan yang ke 2. Materialis pragmatis, yaitu gaya hidup yang sangat konsumtif. Hal ini juga mempertegas cerminan sikap dari janda poligami yang menguasai harta warisan suaminya tersebut.

Sekilas secara kasat mata tiga kasus pertentangan tersebut penyebabnya adalah kurangnya pengetahuan dari para janda poligami terhadap tata cara pembagian warisan menurut KUHP Perdata (Hukum Positif/Hukum Nasional), terlebih menurut Kompilasi Hukum Islam sebagaimana posisi mereka sebagai penganut agama Islam. Dan secara jelas bahwa mereka tidak menggunakan dua teori atau dasar hukum tersebut dalam pembagian warisan dari semendiang meninggalnya suami mereka.

Dalam hal kurangnya pengetahuan atau adanya ketidakmampuan para janda poligami dalam mengaplikasikan ilmu kewarisan ini, maka factor pendidikan dan ekonomi memiliki peranan penting akan dampak yang mereka terima pada saat ini. Sehingga sudah selayaknya stakeholder terkait dalam hal pendidikan dan peningkatan kesejahteraan turut serta ikut membangkitkan semangat dan minat dalam pendidikan dan peningkatan kesejahteraan.

Akan tetapi terlepas dari itu semua unsur atau aspek budaya atau kebiasaan yang menjadi adat juga tidak kalah penting berperan dalam hal ini.

Terkait tentang memahami akan teori atau dasar hukum dari kewarisan khususnya faraidh dalam islam, Sudah semestinya kita sebagai salah satu makhluk Allah SWT yang diberikan akal untuk berpikir dan memahami segala sesuatunya, menggunakan akal tersebut untuk mempelajari sebuah ilmu pengetahuan khususnya ilmu faraidh, serta mengaplikasikannya dalam kehidupan kita sehari-hari. Sebagaimana hadits Rasulullah SAW:

$$
\begin{aligned}
& \text { تعلموا القران وعلموه النا س وتعلموالقلرا ئض وعلموها النا س فاءنى امرؤ مقبوض والعلم مر فو ع ويوشك ان يختلف : } \\
& \text { اثنان فن الفريضة فلا يجدا يخبرهما. (أحرجه احمد والنسائى والدارقطنى) } 11 .
\end{aligned}
$$

Artinya: “ Belajarlah Al-Qur'an dan ajarkanlah dia kepada manusia, dan belajarlah faraidh karena sesungguhnya kau seorang yang akan mati, dan ilmu akan terangkat, dan

11 Rafiq Ahmad, Fish Mawaris, (Jakarta: PT Raja Grafindo, 2001). Hal. 6. 
bisa jadi akan ada dua orang yang berselisih, tetapi tak akan bertemu mereka seorang yang akan mengkabarkan kepada mereka (Hukumnya)" ${ }^{12}$

Dari hadits diatas dapat kita ketahui akan betapa pentingnya mempelajari ilmu pengetahuan (ilmu faraidh), karena apabila tidak ada lagi orang yang mau mempelajari ilmu faraidh maka ada kemungkinan ilmu ini akan musnah. Oleh karena itu, apabila para janda poligami mau mempelajari dan memahami ilmu faraidh ini, maka pertentangan hukum waris itu tidak akan terjadi.

Sedangkan terkait 'urf janda poligami 'urang' banjar yang menguasai harta warisan berdasarkan asas kedekatan dengan suami mereka dan asas senioritas tersebut penulis menganalisa bahwa sikap atau prilaku ini adalah menganut teorinya Snouck Horgronje dan Van Vollenhoven yaitu teori receptive bahwa hukum Islam dapat diberlakukan sepanjang tidak bertentangan atau telah diterima keberlakuannnya oleh hukum adat. Dalam artian hukum Islam mengikuti hukum adat masyarakat sekitar. Sedangkan mereka telah nyata menganut agama Islam.

Oleh karena itu maka penulis berpendapat bahwa sebagai umat Islam, teori yang wajib mereka ikuti adalah teorinya Prof. Hazairin dan Prof. Sayuti Thalib yaitu teori reception a contrario bahwa hukum adat hanya berlaku bila tidak bertentangan dengan hukum agama yang dipeluk oleh masyarakat.

Sikap egois (mau menang sendiri) dan konsumtif yang dimiliki janda poligami pada kasus waris tersebut, akan melahirkan sikap yang sombong (membanggakan diri). Dan ini jelas sudah bertentangan dengan ajaran agama Islam. Allah SWT berfirman:

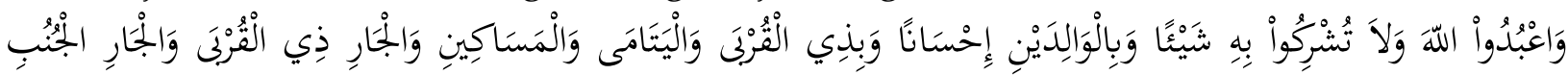

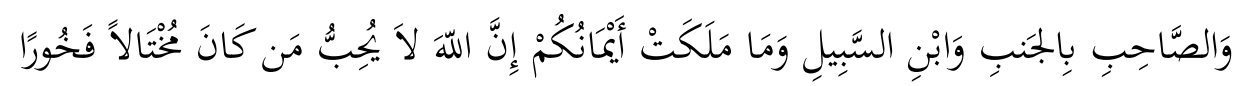

Artinya: "Sembahlah Allah dan janganlah kamu mempersekutukan-Nya dengan sesuatupun. Dan berbuat baiklah kepada dua orang ibu-bapa, karib-kerabat, anak-anak yatim, orang-orang miskin, tetangga yang dekat dan tetangga yang jauh, dan teman sejawat, ibnu sabil, dan hamba sahayamu. Sesungguhnya Allah tidak menyukai orangorang yang sombong dan membangga-banggakan diri." (Q.S An-Nisa : 36). ${ }^{13}$

Sebaliknya, sikap yang harus ditanamkan kepada para janda poligami ini adalah sikap yang adil dan bijaksana. Allah SWT berfirman:

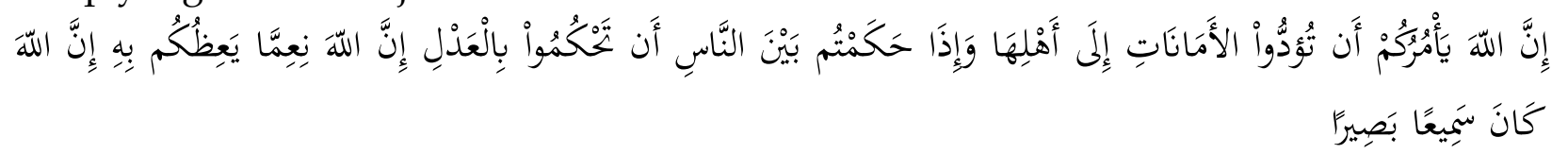

Artinya: "Sesungguhnya Allah menyuruh kamu menyampaikan amanat kepada yang berhak menerimanya, dan (menyuruh kamu) apabila menetapkan hukum di antara manusia supaya kamu menetapkan dengan adil. Sesungguhnya Allah memberi pengajaran yang sebaik-baiknya kepadamu. Sesungguhnya Allah adalah Maha Mendengar lagi Maha Melihat" (Q. S. An-Nisa : 58). ${ }^{14}$

12 A. Hasan, Al Faraa,idh, kitab pembagian pusaka cara islam dengan alas an-alasan Qur'an dan Hadits, cetakan ke XII, (Jakarta: 1972), hal 1.

${ }^{13}$ Departemen Agama RI, Al-Qur'an dan Terjemahnya, op. cit., h. 123.

${ }^{14}$ Departemen Agama RI, Al-Qur'an dan Terjemahny,. op. cit. h. 128. 
Dari keadilan itu maka terpancarlah cahaya keimanan dan berdampak kepada ketakwaan yaitu menegakkan perintah-Nya dengan menjalankan aturan dan menjauhi larangan-Nya sesuai dengan Al-Qur'an. Termasuk dalam hal pembagian warisan pada khususnya. Rasulullah SAW bersabda:

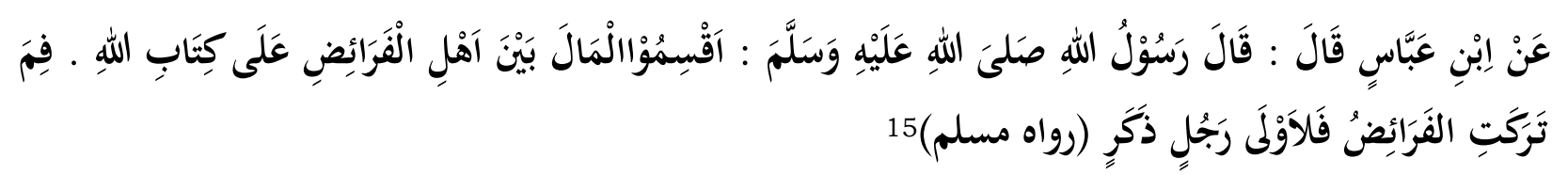

Artinya: Dari Ibnu Abbas, ia berkata: “Rasulullah SAW. Bersabda: 'Bagikanlah harta warisan itu kepada para ahli waris yang mendapat bagian pasti sesuai dengan kitab Allah. Adapun sisanya, maka bagi laki laki yang paling dekat nasabnya'," ${ }^{16}$

Allah SWT juga berfirman:

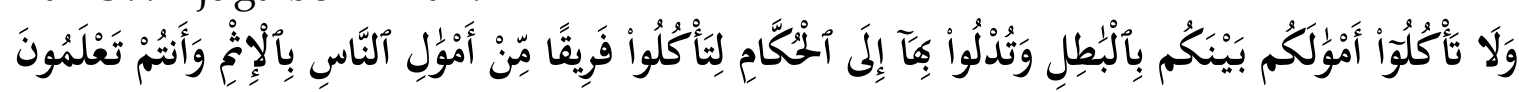

Artinya: "Dan janganlah sebahagian kamu memakan harta sebahagian yang lain di antara kamu dengan jalan yang bathil dan (janganlah) kamu membawa (urusan) harta itu kepada hakim, supaya kamu dapat memakan sebahagian daripada harta benda orang lain itu dengan (jalan berbuat) dosa, padahal kamu mengetahui." (Q.S. Al - Baqarah : 188). $\cdot 17$

Kewarisan janda poligami yang benar menurut hukum islam adalah berdasarkan Al-Qur'an Surah An-Nisa ayat 12 yang telah dicantumkan juga dalam tulisan ini sebelumnya pada poin landasan teori. Demikian pula dibahas dalam Kompilasi Hukum Islam yang juga merupakan landasan hukum pada lingkup Nusantara bagi para hakim Indonesia dalam menyelesaikan beberapa perkara kewarisan. Apabila dilakukan penghitungan berdasarkan hukum faraidh yang benar (Al-Qur'an), maka bagian masing-masing dari janda poligami 'urang' banjar yang melakukan pertentangan tersebut adalah sebagai berikut:

\section{Kasus pertama}

\begin{tabular}{|c|c|c|}
\hline \multirow{3}{*}{ Harta warisan } & : Sebuah rumah & : Rp. 15.000 .000 \\
\hline & Uang tunai di bank & : Rp. 75.000 .000 \\
\hline & Sebidang tanah & : Rp. 40.000 .000 \\
\hline
\end{tabular}
Ahli waris $\quad$ : - Hj. Siti Khadijah (isteri pertama)
- Yati (isteri kedua)
- Saudara laki-laki

\begin{tabular}{|c|c|c|c|}
\hline Ahli waris & Bagian & Asal masalah & Harta penerimaan \\
\hline Isteri kedua & $1 / 4$ & 1 & $\begin{array}{l}\text { 1/4 x Rp. } 130.000 .000 \\
=\text { Rp. } 32.500 .000: 2\end{array}$ \\
\hline
\end{tabular}

\footnotetext{
15 Abi Al- Husayni Muslim, Shabih Muslim, Juz 3 (Beirut : Dar Al-kitab Al-Ilmiah. 1998) , h. 67.

${ }^{16}$ Abid Bisri Mosthofa, Terjemahan Sabih Muslim, Jilid III (Semarang: Asy Syifa.1993), h.146.

17 Departemen Agama RI, Al-Qur'an dan Terjemahnya,loc. cit. h. 46.
} 


$$
=\text { Rp. } 16.250 .000
$$

Saudara laki-laki

Ashabah

3

3/4 x Rp. 130.000 .000

$=$ Rp. 97.500 .000

\section{Kasus kedua}
Harta warisan : Sebidang tanah $\quad$ : Rp. 500.000 .000
2 buah mobil bus : $\underline{\text { Rp. } 140.000 .000}+$
Rp. 640.000 .000

Ahli waris $\quad:-$ Mariah (isteri kedua)

- Hj. Isnaniah (isteri pertama)

- 2 anak laki-laki (anak Hj. Isnaniah)

\begin{tabular}{|c|c|c|c|}
\hline Ahli waris & Bagian & Asal masalah & Harta penerimaan \\
\hline Isteri kedua & & & \\
\hline Isteri pertama & $1 / 8$ & 1 & $\begin{array}{l}1 / 8 \times \text { Rp. } 640.000 .000 \\
=\text { Rp. } 80.000 .000: 2 \\
=\text { Rp. } 40.000 .000\end{array}$ \\
\hline 2 anak laki-laki & Ashabah & 7 & $\begin{array}{l}\text { 7/8 x Rp. } 640.000 .000 \\
=\text { Rp. } 560.000 .000: 2 \\
=\text { Rp. } 280.000 .000\end{array}$ \\
\hline
\end{tabular}

\section{Kasus ketiga}

$\begin{array}{clr}\text { Harta warisan : Sebidang tanah } 40 \mathrm{~m}^{2} & =\text { Rp. } 475.000 .000 \\ \text { Mobil Jimni Katana } & =\text { Rp. } \quad 15.000 .000 \\ \text { Mobil Jet Star } & =\text { Rp. } \quad 7.000 .000 \\ \text { Sebuah rumah } & =\text { Rp. } \quad 52.000 .000\end{array}$

Ahli waris : - Hj. Ruhani (isteri pertama)

- Siti Jaliha (isteri kedua)

- Iyus (anak Siti Juliha)

- 2 anak perempuan (adik Iyus)

- Fi'i dan Utam (anak laki-laki Hj. Ruhani)

- Ina dan Rusna (anak perempuan Hj. Ruhani)

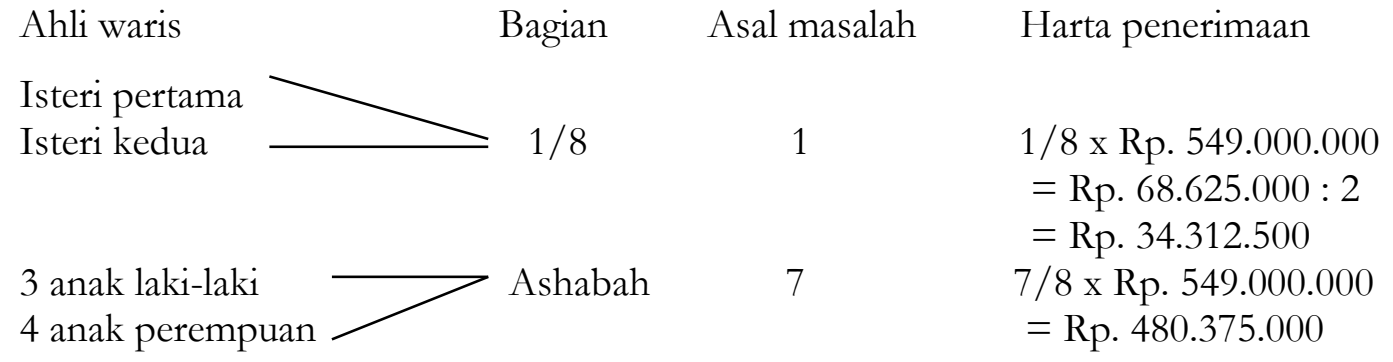

Seorang anak laki-laki mendapat bagian 2/10 x Rp. 480.375.000 = Rp. 96.075.000,- 
Dan bagian anak perempuan 1/10 x Rp. $480.375 .000=$ Rp. 48.037.500,-

Oleh kerena itu berdasarkan analisa secara singkat tersebut penulis dapat memberikan ijtihad kecil-kecilan bahwa janda poligami yang memakan/mengambil haknya janda poligami lainnya itu adalah haram hukumnya. Dan pada dasarnya dari tiga kasus pertentangan hukum kewarisan ini perlu adanya peran serta dari berbagai stakeholder (pihak terkait) lainnya baik itu dari pendidikan, ekonomi, social dan bahkan psikologi antropologi jika memang diperlukan. Disamping itu peranan para pihak di berbagai level juga sangat penting di galakkan seperti para pejabat pemerintah pusat, akademisi, serta masyarakat luas.

Karena saya adalah akademisi, maka memiliki beban kerja dan beban moral untuk mensosialisasikan dan memberikan pemahaman yang baik terkait hal ini, agar tidak terjadi lagi kasus pertentangan hukum kewarisan seperti ini di masa yang akan datang. Aamiin yaa Robbal 'alamin!

\section{Penutup/Simpulan}

Kesimpulan yang dapat penulis sampaikan disini adalah apabila suatu adat istiadat di Indonesia ini bertentangan dengan hukum dan etika dalam syariah maka tidak perlu lagi untuk dipertahankan. Karena posisi hukum tuhan (syariah) adalah hukum yang sangat tinggi dan eternal. Hal ini sesuai dengan teori reception a contrario.

Pentingnya sosialisasi dan pemahaman kepada masyarakat tentang ilmu pengetahuan hukum dalam bidang waris baik itu waris adat, waris hukum positif, dan waris Islam, perlu diperhatikan oleh berbagai pihak dengan berbagai sudut pandang. Upaya tersebut di berikan demi ketentraman dan kedamaian berbagai pihak dalam kewarisan.

Pernikahan yang bagus adalah pernikahan yang sejak awal di niatkan dalam meneguhkan ikatan yang abadi (mitshaqon ghalizon) sehingga upaya dalam proses pencapaiannya itu di laksanakan sebaik-baik mungkin, sesuai tuntunan agama yang rahmatan lil ‘alamin ini.

\section{DAFTAR PUSTAKA}

A. Hasan, Al Faraa,idh, kitab pembagian pusaka cara islam dengan alas an-alasan Qur'an dan Hadits, cetakan ke XII, (Jakarta: 1972).

Abdurrahman, Kompilasi Hukum Islam di Indonesia, (Jakarta: Akademika Pressindo, 1992).

Abi Al -Husayni Muslim, Shahih Muslim, Juz 3 (Beirut : Dar Al-kitab Al-Ilmiah. 1998).

Abid Bisri Mosthofa, Terjemahan Sahih Muslim, Jilid III (Semarang: Asy Syifa.1993).

Ahmad Azhar Basyim, Hukum Waris Indonesia, (Yogyakarta: UTI, 1995).

Al-Qur'an Tajwid Warna, Terjemah Indonesia: Plus Transliterasi Latin (Shahih, 2015). 
Departemen Agama RI, Al-Qur'an dan Terjemahnya, (Jakarta: YPPQ, 1985).

Direktorat pembinaan badan peradilan agama Islam direktorat jenderal pembinaan kelembagaan agama Islam, Kompilasi Hukum Islam di Indonesia, (Jakarta : Departemen Agama RI 2001).

Fathur Rahman, Ilmu Waris, (Bandung: PT. Al- Ma'arif, 1975).

M. Ali Hasan, Hukum Waris Dalam Islam, (Jakarta: Bulan Bintang, 1976).

Moh Anwar BC, Faraid Hukum Waris Islam dan Masalah - masalahnya, (Surabaya: al-Ikhlas, 1981).

Muchlis Maruzi, Pokok Pokok Ilmu Waris, (Jakarta: Pustaka amani, 1980).

Musthafa Diibul Bigha, Ihtisar Hukum - Hukum Islam Praktis, (Semarang : CV. Asy-Syifa, 1994).

Prof. Dr. H. Mahmud Yunus, Hukum Warisan Dalam Islam, (Jakarta : PT. Hidakarya Agung, 1998).

Rafiq Ahmad, Fiqh Mawaris (Jakarta: PT Raja Grafindo, 2001).

Sayyid Sabiq, Fiqh Sunnah XIV, penerjemah: Mudzakir AS., (Bandung: Al- Ma'arif, 1988).

Wayan P Windia, “SISTEM PEWARISAN MENURUT HUKUM ADAT BALI,” n.d. 